\title{
Comparative Study Of Working Conditions Of Elementary School Teachers Under Different Management In Manipur
}

\author{
N Nomika Devi ${ }^{1}$ \\ Assistant Professor \\ D M College of Teacher Education
}

\author{
Nongmeikapam Premika Devi ${ }^{2}$ \\ Guest faculty \\ Department of Psychology, \\ Manipur University
}

\begin{abstract}
Teachers are required not only to impart knowledge in various subjects, they have also to develop the whole personality of the child-body, mind and spirit. The most important equipment of a teacher is his back ground of education and training. A teacher must represent a running stream and not a stagnant pool. The teaching community constitutes a very large segment of employees in Manipur. Both from the point of view of their number and their dispersal all over the state, they distributed a significant service under the state. According to National Policy on Educaion (1992), the living and working conditions of teachers includes pay and allowances, career advancement, retirement and medical benefits, housing facilities, provision of study leave special provisions for women teachers, service conditions, postings and transfers, Teacher's Welfare teachers' participation and recruitments. The main objective is to study the working conditions of teachers $f$ elementary schools with respect to management. Out of 600 teachers, 268 teachers were from 38 Elementary Government school, 122 teachers from 26 Elementary Aided schools and 210 teachers from 32 Elementary Private schools. It was found that $47.62 \%$ of private schools have pucca building while that of Government and Aided schools are 35.82\% and $20.48 \%$ respectively. Lack of the minimum essential facilities in elementary schools exist in all three types of school in which Government schools are much lacking behind the other counter parts. School inspection on regular basis is found to be lacking in Government (48.88\%) and Aided schools (49.18\%). Private school teachers show highest in Heavy work-load(61.90\%) and miscillenious work $(20.95 \%)$. service conditions of Government teachers are in better position as compared to Aided and Private school teachers. The majority of Private school teachers reported that Salaries are paid in time as compared to other counter parts. service conditions of Government teachers are in better position as compared to Aided and Private school teachers. Parents-Teachers Association (PTA) are found to be highest in Government schools (67.21\%) and lowest in Private schools (53.33\%). It was found $73.50 \%$ of Government, $72.89 \%$ of Aided and $43.33 \%$ of Private school teachers do not have computer knowledge.
\end{abstract}

Key Words: Aided, Elementary, Government, Private, School Teachers, Manipur, Working Conditions. 


\section{INTRODUCTION}

Teachers occupy a crucial position in the educational system. They have to perform a very important task, viz. the development of human resource - the resource that lies in the budding children and youth. Teachers are required not only to impart knowledge in various subjects, they have also to develop the whole personality of the child-body, mind and spirit. The most important equipment of a teacher is his back ground of education and training. A teacher must represent a running stream and not a stagnant pool.

The teaching community constitutes a very large segment of employees in Manipur. Both from the point of view of their number and their dispersal all over the state, they distributed a significant service under the state. With the expansion of schools, the growth of teachers at the Elementary stage also increased.

In the opinion of the Kothari Commission 1964-66, it is necessary that intensive and continued efforts be made to raise the economic, social and professional status of the teachers in order to attract young men and women of ability to the profession and to retain them in it as dedicated, enthusiastic and contended workers. Besides, it is necessary that provision of adequate remuneration, opportunities for professional advancement and favourable conditions of service and work are imposed to attract the people. Accordingly, it can be assumed that favourable conditions of service and work comprises of adequate facilities working hours, conduct and discipline, service conditions, professional advancements, residential accommodation and participation of teachers. The Programme of Action (POA), 1986 has elucidated that "strong, united and responsible teachers' organizations are necessary for the protection of the dignity and rights of teachers as also for ensuring proper professional conduct of teachers". Besides their struggle for improving the service conditions, it is desirable that the teachers associations should clearly involve themselves in ensuring credibility and capability of teachers by developing a code of conduct and professional ethics as well as participating in the nation building activities like Education for All and Eradication of Mass Illiteracy.

According to National Policy on Education (1992), the living and working conditions of teachers includes pay and allowances, career advancement, retirement and medical benefits, housing facilities, provision of study leave special provisions for women teachers, service conditions, postings and transfers, Teacher's Welfare teachers' participation and recruitment .

The State Education Commission, Manipur 1992 also reported that the teachers are sore about their low emoluments, poor conditions of service and lack of even essential physical infrastructure and proper teaching-learning environment in most of the schools. The matter calls for serious attention. It was reported that the teachers of private aided and unaided private schools do not have proper service conditions.. Teachers in private recognized unaided schools were being paid a consolidated salary which was much lower than the total emoluments of the corresponding government teachers. This we are afraid, may tantamount to discrimination and exploitation of the teachers (Govt. of Manipur, 1992, p.65).

The State Education Commission, 1992 observes that "Lack of even the minimum essential facilities in schools particularly elementary schools, is a serious handicap in raising the quality of school education in the state. Physical facilities have not kept pace with phenomenal expansion in education since independence. Drinking water facility does not exist in nearly $75 \%$ of primary and $50 \%$ of Junior high schools. Toilet facility is not available in nearly $80 \%$ primary 
and $50 \%$ junior high schools. Several junior high schools and high schools do not have separate toilets for girls. Nearly $1 / 3^{\text {rd }}$ Government schools do not have library facilities and teaching aids. $40 \%$ do not have playgrounds. Even blackboards are lacking in a large number of L.P./Primary Schools especially in hill Districts council schools. There are more than 2000 primary schools which are short of furniture for pupils.

Throughout the ages, the role and importance of teachers have been recognized by different commissions and committees. To attract suitable persons to the teaching profession is, therefore, of the highest importance. For their effective functioning necessary facilities must be provided so that he may be able to lead a contended life and discharge his duties with public affairs like any other free citizen in today's democracy.

\section{OBJECTIVE}

The main objective is to study the working conditions of teachers f elementary schools with respect to management.

\section{MATERIALS AND METHODS}

\section{Sample Size}

The total population of the study consisted of teachers teaching in elementary schools of valley districts of Manipur. The investigator selected representative sample of 96 schools from different managements on the basis of stratified cluster sampling technique. Out of 600 teachers, 268 teachers were from 38 Elementary Government school, 122 teachers from 26 Elementary Aided schools and 210 teachers from 32 Elementary Private schools.

\section{Tools}

a) Personal Data Sheet

b) School Information Schedule

c) Teacher Working Conditions Questionnaire.

The questionnaire for working conditions are divided into eight sub-headings: Management, working-load, service conditions, salary, transfer and posting, in-service training, school climate and teaching-learning process. All items were provided with two alternatives - Yes or No.

\section{RESULTS AND DISCUSSION}

School building with respect to management

Table No. 1: School Building with Respect to Management (In Percent)

\begin{tabular}{|c|l|l|l|l|l|}
\hline S1 & $\begin{array}{l}\text { Type of School } \\
\text { Building }\end{array}$ & $\begin{array}{l}\text { No. of } \\
\text { Respondents }\end{array}$ & Pucca & $\begin{array}{l}\text { Partially- } \\
\text { pucca }\end{array}$ & Kutcha \\
\hline \multirow{2}{*}{1} & Government & 268 & 35.82 & 42.91 & 21.29 \\
\cline { 2 - 6 } 2 & Aided & 122 & 20.49 & 38.52 & 40.98 \\
\hline 3 & Private & 210 & 47.62 & 33.81 & 18.57 \\
\hline
\end{tabular}

From Table No. 1 , it is seen $47.62 \%$ of private schools have pucca building while that of Government and Aided schools are $35.82 \%$ and $20.48 \%$ respectively. This shows that the school buildings of elementary schools need to be improved especially in the Government and Aided schools. It is also observed that $40.98 \%$ of Aided schools have Kutcha building. Even though the 
Private schools are in better position as compared to Government and Aided schools, $18.57 \%$ of the private schools have Kutcha building.

It may be summarized that the private schools have maximum number of pucca building (47.62\%) while the Aided schools have minimum number of Pucca building with 20.49\%. The Government schools have maximum number of Partially-pucca buildings with $42.91 \%$ while the Aided schools have maximum number of Kutcha building with $40.98 \%$.

\section{School Facilities with Respect to Management}

\section{Table No. 2: Facilities in Elementary Schools with Respect to Management (In Percent)}

\begin{tabular}{|c|c|c|c|c|c|}
\hline \multirow{2}{*}{$\begin{array}{l}\text { Item } \\
\text { No. }\end{array}$} & \multirow[t]{2}{*}{ Dimensions } & \multirow{2}{*}{$\begin{array}{l}\text { No. of } \\
\text { Respondents }\end{array}$} & \multirow{2}{*}{$\begin{array}{l}\text { Type of } \\
\text { Management }\end{array}$} & \multicolumn{2}{|c|}{ Responses } \\
\hline & & & & Yes & No \\
\hline \multirow[t]{3}{*}{1} & \multirow[t]{3}{*}{ Adequate Room } & 268 & Government & 67.54 & 32.46 \\
\hline & & 122 & Aided & 91.80 & 8.20 \\
\hline & & 210 & Private & 99.05 & 0.95 \\
\hline \multirow[t]{3}{*}{2} & \multirow[t]{3}{*}{ Separate Staff Room } & 268 & Government & 61.19 & 38.80 \\
\hline & & 122 & Aided & 63.93 & 36.06 \\
\hline & & 210 & Private & 76.19 & 23.80 \\
\hline \multirow[t]{3}{*}{3} & \multirow[t]{3}{*}{ Adequate Library } & 268 & Government & 30.97 & 69.02 \\
\hline & & 122 & Aided & 37.70 & 62.30 \\
\hline & & 210 & Private & 56.19 & 43.80 \\
\hline \multirow[t]{3}{*}{4} & \multirow[t]{3}{*}{ Toilet Facility } & 268 & Government & 63.81 & 36.19 \\
\hline & & 122 & Aided & 74.59 & 25.40 \\
\hline & & 210 & Private & 95.24 & 4.76 \\
\hline \multirow[t]{3}{*}{5} & \multirow[t]{3}{*}{ Separate toilet for staff } & 268 & Government & 21.64 & 78.35 \\
\hline & & 122 & Aided & 32.79 & 67.21 \\
\hline & & 210 & Private & 56.19 & 43.80 \\
\hline \multirow[t]{3}{*}{6} & \multirow[t]{3}{*}{ Separate for boys \& girls } & 268 & Government & 21.64 & 78.35 \\
\hline & & 122 & Aided & 34.43 & 65.57 \\
\hline & & 210 & Private & 68.57 & 31.42 \\
\hline \multirow[t]{3}{*}{7.} & \multirow[t]{3}{*}{ Safe Drinking water } & 268 & Government & 33.96 & 66.04 \\
\hline & & 122 & Aided & 43.44 & 56.55 \\
\hline & & 210 & Private & 54.76 & 45.23 \\
\hline \multirow[t]{3}{*}{8.} & \multirow[t]{3}{*}{ Health Care centre near school } & 268 & Government & 57.83 & 42.16 \\
\hline & & 122 & Aided & 55.74 & 44.26 \\
\hline & & 210 & Private & 63.33 & 36.66 \\
\hline \multirow[t]{3}{*}{9.} & \multirow{3}{*}{ Conducive Classroom } & 268 & Government & 65.29 & 34.70 \\
\hline & & 122 & Aided & 70.49 & 29.51 \\
\hline & & 210 & Private & 77.61 & 22.38 \\
\hline \multirow[t]{3}{*}{10.} & \multirow[t]{3}{*}{ Neat \& Clean premises } & 268 & Government & 67.21 & 32.79 \\
\hline & & 122 & Aided & 30.59 & 69.40 \\
\hline & & 210 & Private & 72.38 & 27.61 \\
\hline \multirow[t]{3}{*}{11.} & \multirow[t]{3}{*}{ Safai Karmachary } & 268 & Government & 35.83 & 64.17 \\
\hline & & 122 & Aided & 48.36 & 41.64 \\
\hline & & 210 & Private & 70.47 & 29.52 \\
\hline 12. & Adequate Furniture & 268 & Government & 47.01 & 52.98 \\
\hline & & 122 & Aided & 49.18 & 50.82 \\
\hline & & 210 & Private & 80 & 20 \\
\hline
\end{tabular}


The Table No. 2 shows the facilities in school with respect to management in percent. Out of twelve areas ten areas are found to be significant. The private school are better off than the other counter parts in the areas viz. Adequate Room (99.05\%), Separate staff room (76.19\%), Adequate Library (56.19\%), Toilet facility (95.24\%), Separate toilet for staff (56.19\%), Separate toilet for boys and girls (68.57\%), Safe drinking water (54.76\%), Conducive classroom (77.61\%), Safai Karmachary (70.47\%), and Adequate Furniture (80\%). The Government schools are in lowest position in all the areas viz. Adequate Room (67.54\%), Separate staff room (61.19\%), Adequate Library (30.97\%), Toilet facility (63.81), Separate toilet for staff (21.64\%), Separate toilet for boys and girls (21.64\%), Safe drinking water (33.96\%), Conducive classroom(65.29\%), Safai Karmachary (35.83\%), and Adequate Furniture (47.01\%).

It can be concluded that lack of the minimum essential facilities in elementary schools exist in all three types of school in which Government schools are much lacking behind the other counter parts. About $32.47 \%$ of Government schools do not have adequate room while that of Aided and Private schools are $8.20 \%$ and $0.95 \%$ respectively. Library facility is in poor state, with 56.19\%, 30.97\% and 37.70\% in Private, Government and Aided schools respectively. Toilet facility is not available in $25.40 \%$ of Aided schools, $36.19 \%$ of Government schools, and $4.76 \%$ of Private schools. Separate toilet for staff does not exist in $67.21 \%$ of Aided schools, $78.35 \%$ of Government and $43.80 \%$ of Private schools. Several elementary schools do not have separate toilet for boys and girls. About $65.57 \%, 78.35 \%$ and $31.42 \%$ of Aided, Government and Private schools respectively do not have separate toilet for boys and girls. Safe drinking water facility is not available in 56.55\%, 66.04\% and $45.23 \%$ of Aided, Government and Private schools respectively. It is found that $77.61 \%, 65.29 \%$ and $70.49 \%$ of Private, Government and Aided schools respectively have conducive classroom. A number of schools in Aided and Government do not have Safai Karmachary with $41.64 \%$ and $64.17 \%$ respectively while that of Private is $29.52 \%$. Aided and Government schools show high percentage of lack of furniture with $50.82 \%$ and $52.98 \%$ respectively while that of Private is $20 \%$. The essential facilities in Government elementary schools are in poor condition as compared to other counter parts.

School Management With Respect to Management

Table No. 3: School Management with Respect to Management (In Percent)

\begin{tabular}{|c|c|c|c|c|c|}
\hline \multirow{2}{*}{$\begin{array}{l}\text { Item } \\
\text { No. }\end{array}$} & \multirow[t]{2}{*}{ Dimensions } & \multirow{2}{*}{$\begin{array}{l}\text { No. of } \\
\text { Respondents }\end{array}$} & \multirow{2}{*}{$\begin{array}{l}\text { Type of } \\
\text { Management }\end{array}$} & \multicolumn{2}{|c|}{ Responses } \\
\hline & & & & Yes & No \\
\hline \multirow[t]{3}{*}{1.} & \multirow{3}{*}{$\begin{array}{l}\text { Head takes action for } \\
\text { development }\end{array}$} & 268 & Government & 73.13 & 26.86 \\
\hline & & 122 & Aided & 76.23 & 23.77 \\
\hline & & 210 & Private & 78.10 & 21.90 \\
\hline \multirow[t]{3}{*}{2.} & \multirow{3}{*}{$\begin{array}{l}\text { Teachers reach school } \\
\text { before assembly }\end{array}$} & 268 & Government & 63.81 & 36.19 \\
\hline & & 122 & Aided & 63.93 & 36.07 \\
\hline & & 210 & Private & 79.05 & 20.95 \\
\hline \multirow[t]{3}{*}{3.} & \multirow{3}{*}{$\begin{array}{l}\text { Disciplined the inefficient } \\
\text { teachers }\end{array}$} & 268 & Government & 74.63 & 25.37 \\
\hline & & 122 & Aided & 70.49 & 29.51 \\
\hline & & 210 & Private & 71.43 & 28.57 \\
\hline \multirow[t]{3}{*}{4.} & \multirow[t]{3}{*}{ Students discipline } & 268 & Government & 70.14 & 29.86 \\
\hline & & 122 & Aided & 96.72 & 3.28 \\
\hline & & 210 & Private & 97.62 & 2.38 \\
\hline
\end{tabular}




\begin{tabular}{|c|l|l|l|l|l|}
\hline 5. & Planning \& Policy making & 268 & Government & 70.15 & 29.85 \\
\cline { 4 - 6 } & & 122 & Aided & 72.13 & 27.87 \\
\cline { 3 - 6 } & & 210 & Private & 57.14 & 42.86 \\
\hline \multirow{2}{*}{6.} & \multirow{2}{*}{ School inspection } & 268 & Government & 51.12 & 48.88 \\
\cline { 3 - 6 } & & 122 & Aided & 50.82 & 49.18 \\
\cline { 3 - 6 } & & 210 & Private & 67.14 & 32.86 \\
\hline
\end{tabular}

From the Table No.3, Private school teachers reported to have highest percentage in yes responses in terms of Teachers reach before assembly, Students' discipline, and School inspection with 79.05\%, 97.62\% and 67.14\% except for Planning and policy making( 57.14\%). The Government school teachers $(51.12 \%)$ shows higher percentage than Aided school teachers in terms of School inspection. The Aided school teachers are better position in terms of Teachers reach school before assembly(63.93\%), Students' discipline (96.72\%) and Planning and policy making $(50.82 \%)$ as compared to Government school teachers. Out of all the areas of School management, School inspection on regular basis is found to be lacking in Government (48.88\%) and Aided schools (49.18\%).

Work-Load of Teachers of Elementary Schools with Respect To Management

Table No. 4: Work Load with Respect to Management (In Percent)

\begin{tabular}{|c|c|c|c|c|c|}
\hline \multirow{2}{*}{$\begin{array}{c}\text { Item } \\
\text { No. }\end{array}$} & \multirow[t]{2}{*}{ Dimensions } & \multirow{2}{*}{$\begin{array}{l}\text { No. of } \\
\text { Respondents }\end{array}$} & \multirow{2}{*}{$\begin{array}{l}\text { Type of } \\
\text { Management }\end{array}$} & \multicolumn{2}{|c|}{ Responses } \\
\hline & & & & Yes & No \\
\hline \multirow[t]{3}{*}{1} & \multirow[t]{3}{*}{ Non-teaching works } & 268 & Government & 57.46 & 42.54 \\
\hline & & 122 & Aided & 42.62 & 57.38 \\
\hline & & 210 & Private & 40.95 & 59.04 \\
\hline \multirow[t]{3}{*}{2} & \multirow[t]{3}{*}{ Collection of fees } & 268 & Government & 12.69 & 87.31 \\
\hline & & 122 & Aided & 13.11 & 86.89 \\
\hline & & 210 & Private & 13.33 & 86.67 \\
\hline \multirow[t]{3}{*}{3} & \multirow[t]{3}{*}{ Distribution of circulars } & 268 & Government & 19.40 & 80.60 \\
\hline & & 122 & Aided & 22.13 & 77.87 \\
\hline & & 210 & Private & 21.90 & 78.10 \\
\hline \multirow[t]{3}{*}{4} & \multirow[t]{3}{*}{ Maintaining Library books } & 268 & Government & 19.40 & 80.60 \\
\hline & & 122 & Aided & 18.85 & 81.15 \\
\hline & & 210 & Private & 19.52 & 80.48 \\
\hline \multirow[t]{3}{*}{5} & \multirow[t]{3}{*}{ Census survey } & 268 & Government & 35.07 & 64.93 \\
\hline & & 122 & Aided & 38.52 & 61.48 \\
\hline & & 210 & Private & 8.57 & 91.43 \\
\hline \multirow[t]{3}{*}{6} & \multirow[t]{3}{*}{ Miscillenious } & 268 & Government & 13.43 & 86.57 \\
\hline & & 122 & Aided & 7.38 & 92.62 \\
\hline & & 210 & Private & 20.95 & 79.05 \\
\hline \multirow[t]{3}{*}{7} & \multirow[t]{3}{*}{ Heavy Work-laod } & 268 & Government & 44.03 & 55.97 \\
\hline & & 122 & Aided & 61.48 & 38.52 \\
\hline & & 210 & Private & 61.90 & 38.10 \\
\hline \multirow[t]{3}{*}{8.} & \multirow[t]{3}{*}{ Remedial classes } & 268 & Government & 39.55 & 60.44 \\
\hline & & 122 & Aided & 59.83 & 40.16 \\
\hline & & 210 & Private & 55.24 & 44.76 \\
\hline 9. & Insufficient number of & 268 & Government & 49.25 & 50.74 \\
\hline
\end{tabular}




\begin{tabular}{|l|l|l|l|l|l|}
\hline \multirow{2}{*}{ teachers } & 122 & Aided & 54.91 & 45.08 \\
\cline { 3 - 6 } & & 210 & Private & 25.71 & 74.29 \\
\hline
\end{tabular}

Table No.4 shows that Non-teaching works was found to be highest among the Government elementary school teachers with $57.46 \%$, followed by Aided school teachers $(42.62 \%)$ and closely followed by Private school teachers(40.95). In terms of Census survey, Aided school teachers show highest (38.52\%), closely followed by Government (35.07\%) and least by Private school teachers (8.57\%). The Private school teachers are highest in terms of Miscillenious work followed by Government and Aided subsequently with 20.95\%, 13.43\% and $7.38 \%$ respectively. In terms of Heavy work-load, Private school teachers show highest subsequently followed by Aided school teachers and Government teachers with $61.90 \%, 61.48 \%$ and $44.03 \%$ respectively. Aided school teachers show highest in terms of Remedial classes $(59.83 \%)$ and Insufficient teachers $(54.91 \%)$. Remedial classes are least done by Government school teachers(39.55\%). Insufficient number of teachers in Government school is $49.25 \%$ while that of Private school is $25.71 \%$.

Thus, it may be concluded that Government teachers show highest in Non-teaching works(57.46\%). Aided school teachers show highest in Census survey(38.52\%), Remedial classes(59.83) and In-sufficient number of teachers(54.91\%). Private school teachers show highest in Heavy work-load(61.90\%) and miscillenious work(20.95\%).

Service Conditions of Teachers of Elementary Schools With Respect to Management

Table No. 5: Service Conditions with respect to management (In Percent)

\begin{tabular}{|c|c|c|c|c|c|}
\hline \multirow{2}{*}{$\begin{array}{l}\text { Item } \\
\text { No. }\end{array}$} & \multirow[t]{2}{*}{ Dimensions } & \multirow{2}{*}{$\begin{array}{l}\text { No. of } \\
\text { Responden } \\
\text { ts }\end{array}$} & \multirow{2}{*}{$\begin{array}{l}\text { Type of } \\
\text { Managemen } \\
t\end{array}$} & \multicolumn{2}{|c|}{ Responses } \\
\hline & & & & Yes & No \\
\hline \multirow[t]{3}{*}{1} & \multirow{3}{*}{$\begin{array}{l}\text { Recruitment : Selection } \\
\text { cum Interview }\end{array}$} & 268 & Government & 78.36 & 21.64 \\
\hline & & 122 & Aided & 64.75 & 35.25 \\
\hline & & 210 & Private & 78.10 & 21.90 \\
\hline \multirow[t]{3}{*}{2} & \multirow{3}{*}{$\begin{array}{l}\text { Satisfied with mode of } \\
\text { selection }\end{array}$} & 268 & Government & 55.97 & 44.03 \\
\hline & & 122 & Aided & 50 & 50 \\
\hline & & 210 & Private & 97.01 & 2.99 \\
\hline \multirow[t]{3}{*}{3} & \multirow[t]{3}{*}{ Medical benefits } & 268 & Government & 97.01 & 2.99 \\
\hline & & 122 & Aided & 18.03 & 81.97 \\
\hline & & 210 & Private & 25.71 & 74.29 \\
\hline \multirow{3}{*}{4} & \multirow[t]{3}{*}{ Promotion in proper time } & 268 & Government & 32.84 & 67.16 \\
\hline & & 122 & Aided & 22.13 & 77.87 \\
\hline & & 210 & Private & 31.43 & 68.57 \\
\hline \multirow[t]{3}{*}{5} & \multirow{3}{*}{$\begin{array}{l}\text { Study leave for higher } \\
\text { qualification }\end{array}$} & 268 & Government & 55.22 & 44.78 \\
\hline & & 122 & Aided & 50.82 & 49.18 \\
\hline & & 210 & Private & 35.71 & 64.29 \\
\hline \multirow{3}{*}{6} & \multirow{3}{*}{$\begin{array}{l}\text { Pension, Gratuity \& } \\
\text { Provident fund }\end{array}$} & 268 & Government & 97.01 & 2.99 \\
\hline & & 122 & Aided & 18.03 & 81.97 \\
\hline & & 210 & Private & 21.43 & 78.57 \\
\hline
\end{tabular}

From table No.5, it is found that Government elementary school teachers show higher percentage in all the five areas as compared to other counterparts. About $78.36 \%$ of Government 
school teachers reported that their recruitment were done by selection cum interview while that of Private and Aided school teachers is $78.10 \%$ and $64.75 \%$ respectively. In terms of Satisfied with mode of selection of Government teachers, it is found Government teachers $(55.97 \%)$ are highest, closely followed by Aided(50\%) and the least was among Private school teachers(29.52\%). Majority of the Aided (81.97\%) and Private (74.29\%) school teachers do not enjoy medical benefits. Majority of Government (97.01\%) teachers reported to enjoy Medical benefits. About 55.22\% of Government teachers reported that Study leave for higher education are provided, while that of Aided school teachers reported and the Private school teachers reported about $50.82 \%$ and $35.71 \%$ respectively. In terms of Pension, Gratuity and Provident fund, $97.01 \%$ teachers in Government school enjoy the scheme. While that of Aided and Private schools, show low percent with $18.03 \%$ and $21.43 \%$ respectively.

It may be concluded that service conditions of Government teachers are in better position as compared to Aided and Private school teachers. About $70.48 \%$ of Private school teachers are not satisfied with mode of selection. About $81.97 \%$ and $74.29 \%$ of Aided and Private school teachers respectively do not get medical facilities. On the other hand, majority of government school teachers enjoyed medical benefits (67.91\%). Study leave for higher qualification among the private school teachers are low with $35.71 \%$ only. Majority of the Aided and Private school teachers do not enjoy Pension, Gratuity and Provident fund which is about $81.97 \%$ and $78.57 \% .5$ Salary of Teachers of Elementary School with Respect to Management

\begin{tabular}{|c|c|c|c|c|c|}
\hline \multirow{2}{*}{$\begin{array}{l}\text { Item } \\
\text { No. }\end{array}$} & \multirow[t]{2}{*}{ Dimensions } & \multirow{2}{*}{$\begin{array}{l}\text { No. of } \\
\text { Respondents }\end{array}$} & \multirow{2}{*}{$\begin{array}{l}\text { Type of } \\
\text { Management }\end{array}$} & \multicolumn{2}{|c|}{ Responses } \\
\hline & & & & Yes & No \\
\hline \multirow[t]{3}{*}{1} & \multirow[t]{3}{*}{ Salaries paid in time } & 268 & Government & 23.88 & 76.12 \\
\hline & & 122 & Aided & 21.31 & 78.69 \\
\hline & & 210 & Private & 74.29 & 25.71 \\
\hline \multirow[t]{3}{*}{2} & \multirow{3}{*}{$\begin{array}{l}\text { Allowances for Head-in- } \\
\text { charge }\end{array}$} & 268 & Government & 32.09 & 67.91 \\
\hline & & 122 & Aided & 21.31 & 78.69 \\
\hline & & 210 & Private & 38.10 & 61.90 \\
\hline \multirow[t]{3}{*}{3} & \multirow{3}{*}{$\begin{array}{l}\text { Increment on acquiring } \\
\text { higher education }\end{array}$} & 268 & Government & 48.51 & 51.49 \\
\hline & & 122 & Aided & 45.90 & 54.10 \\
\hline & & 210 & Private & 45.24 & 54.76 \\
\hline \multirow[t]{3}{*}{4} & \multirow[t]{3}{*}{ Satisfied with salary } & 268 & Government & 73.88 & 26.12 \\
\hline & & 122 & Aided & 48.36 & 51.64 \\
\hline & & 210 & Private & 44.76 & 55.24 \\
\hline
\end{tabular}

Table No. 6 depicts Salary of elementary school teachers in percent. The majority of Private school teachers reported that Salaries are paid in time as compared to other counter parts. It is found that $23.88 \%$ of Government teachers and $21.31 \%$ of Aided teachers reported that Salaries are paid in time while that of Private school teachers are found to be $74.29 \%$. About $38.10 \%$ of Private, $32.09 \%$ of Government and $21.31 \%$ of Aided school teachers are given Allowances for Head-in-charge. It is found majority of Government school teachers are Satisfied with salary. About $73.88 \%$ of Government teachers are Satisfied with salary on the other hand, $48.36 \%$ of Aided and $44.76 \%$ of Private school teachers are Satisfied with salary.

Transfer and Posting of Elementary School Teachers With Respect to Management 
Table No. 7: Transfer And Posting ( In Percent)

\begin{tabular}{|c|c|c|c|c|c|}
\hline \multirow{2}{*}{$\begin{array}{l}\text { Item } \\
\text { No. }\end{array}$} & \multirow[t]{2}{*}{ Dimensions } & \multirow{2}{*}{$\begin{array}{l}\text { No. of } \\
\text { Respondents }\end{array}$} & \multirow{2}{*}{$\begin{array}{l}\text { Type of } \\
\text { Management }\end{array}$} & \multicolumn{2}{|c|}{ Responses } \\
\hline & & & & Yes & No \\
\hline \multirow{3}{*}{1} & \multirow{3}{*}{$\begin{array}{l}\text { Posted in remote /hill } \\
\text { areas }\end{array}$} & 268 & Government & 31.34 & 68.66 \\
\hline & & 122 & Aided & 3.28 & 96.72 \\
\hline & & 210 & Private & 0.95 & 99.05 \\
\hline \multirow{3}{*}{2} & \multirow{3}{*}{$\begin{array}{l}\text { Transfer done before } \\
\text { commencement of } \\
\text { academic session }\end{array}$} & 268 & Government & 29.85 & 70.15 \\
\hline & & 122 & Aided & 0 & 100 \\
\hline & & 210 & Private & 0 & 100 \\
\hline \multirow{3}{*}{3} & \multirow{3}{*}{$\begin{array}{l}\text { Posted with regard to the } \\
\text { need of the concern } \\
\text { subjects }\end{array}$} & 268 & Government & 39.18 & 61.19 \\
\hline & & 122 & Aided & 0 & 100 \\
\hline & & 210 & Private & 0 & 100 \\
\hline
\end{tabular}

About $0.95 \%$ of Private school teachers were found to have been posted in remote/hill areas, while $31.34 \%$ are reported by Government teachers. It is found that Aided and Private school teachers do not have transfer and posting system. Therefore, the areas Transfer done before commencement of academic session and Posted with regard to the need of the concern subjects are not applicable to Aided and Private school teachers. In the case of Government teachers, 29.85\% reported that transfer is done before commencement of academic session and $39.18 \%$ reported that posting are done with regard to the need of the concern subjects

Thus, it may be concluded that the Transfer and posting is not applicable to Aided and Private school teachers. In case of Government school teachers, 68.66\% of them have never been posted to remote/hill areas, $70.15 \%$ of them are of the opinion that Transfer is not done before the commencement of academic session and $61.19 \%$ opined that posting is not done with regard to the need of the concern subjects.

In-Service Programmes of Teachers of Elementary School with Respect to Management.

Table No. 7: In-Service Training Programme with Respect to Management (In Percent)

\begin{tabular}{|c|c|c|c|c|c|}
\hline \multirow{2}{*}{$\begin{array}{l}\text { Item } \\
\text { No. }\end{array}$} & \multirow[t]{2}{*}{ Dimensions } & \multirow{2}{*}{$\begin{array}{l}\text { No. of } \\
\text { Respondents }\end{array}$} & \multirow{2}{*}{$\begin{array}{l}\text { Type of } \\
\text { Management }\end{array}$} & \multicolumn{2}{|c|}{ Responses } \\
\hline & & & & Yes & No \\
\hline \multirow{3}{*}{1} & \multirow{3}{*}{$\begin{array}{l}\text { Attended training } \\
\text { programmes }\end{array}$} & 268 & Government & 70.90 & 29.10 \\
\hline & & 122 & Aided & 65.57 & 34.42 \\
\hline & & 210 & Private & 47.62 & 52.38 \\
\hline \multirow{3}{*}{2} & \multirow{3}{*}{$\begin{array}{l}\text { DIETs \& other training } \\
\text { institutes provide } \\
\text { satisfactory training }\end{array}$} & 268 & Government & 56.67 & 34.33 \\
\hline & & 122 & Aided & 63.11 & 36.89 \\
\hline & & 210 & Private & 62.86 & 37.14 \\
\hline
\end{tabular}

From the Table No.7, the Government(70.90\%) and Aided school(65.57\%) teachers are more in the positive side as compared to Private(47.62\%) school teachers in terms of Attended training programmes. 
School Climate with Respect to Management

Table No.8: School Climate with respect to Management (In Percent)

\begin{tabular}{|c|c|c|c|c|c|}
\hline \multirow{2}{*}{$\begin{array}{l}\text { Item } \\
\text { No. }\end{array}$} & \multirow[t]{2}{*}{ Dimensions } & \multirow{2}{*}{$\begin{array}{l}\text { No. of } \\
\text { Respondents }\end{array}$} & \multirow{2}{*}{$\begin{array}{l}\text { Type of } \\
\text { Management }\end{array}$} & \multicolumn{2}{|c|}{ Responses } \\
\hline & & & & Yes & No \\
\hline \multirow[t]{3}{*}{1} & \multirow[t]{3}{*}{ Quite surrounding } & 268 & Government & 68.66 & 31.34 \\
\hline & & 122 & Aided & 64.75 & 35.25 \\
\hline & & 210 & Private & 67.14 & 32.86 \\
\hline \multirow[t]{3}{*}{2} & \multirow{3}{*}{ Cordial relationship } & 268 & Government & 77.61 & 22.39 \\
\hline & & 122 & Aided & 77.05 & 22.95 \\
\hline & & 210 & Private & 72.38 & 27.62 \\
\hline \multirow[t]{3}{*}{3} & \multirow{3}{*}{$\begin{array}{l}\text { Parents-Teachers } \\
\text { Association }\end{array}$} & 268 & Government & 68.66 & 31.34 \\
\hline & & 122 & Aided & 67.21 & 32.79 \\
\hline & & 210 & Private & 53.33 & 46.67 \\
\hline \multirow[t]{3}{*}{ 3(a) } & \multirow[t]{3}{*}{ Useful for development } & 268 & Government & 85.86 & 14.14 \\
\hline & & 122 & Aided & 47.54 & 52.45 \\
\hline & & 210 & Private & 82.14 & 17.86 \\
\hline \multirow[t]{3}{*}{4} & \multirow[t]{3}{*}{ Local people help } & 268 & Government & 52.24 & 47.76 \\
\hline & & 122 & Aided & 62.30 & 37.70 \\
\hline & & 210 & Private & 44.76 & 55.24 \\
\hline \multirow[t]{3}{*}{5} & \multirow[t]{3}{*}{ No Outside pressure } & 268 & Government & 54.47 & 45.52 \\
\hline & & 122 & Aided & 73.77 & 26.23 \\
\hline & & 210 & Private & 70.95 & 29.05 \\
\hline \multirow[t]{3}{*}{6} & \multirow{3}{*}{$\begin{array}{l}\text { Organization come for } \\
\text { inspection }\end{array}$} & 268 & Government & 54.10 & 45.90 \\
\hline & & 122 & Aided & 52.46 & 47.54 \\
\hline & & 210 & Private & 45.71 & 54.29 \\
\hline \multirow[t]{3}{*}{ 6(a) } & \multirow{3}{*}{$\begin{array}{l}\text { Inspection by other } \\
\text { organization can be a } \\
\text { substitute to the supervisor's } \\
\text { inspection }\end{array}$} & 145 & Government & 24.83 & 75.17 \\
\hline & & 64 & Aided & 21.88 & 78.12 \\
\hline & & 96 & Private & 46.88 & 53.125 \\
\hline
\end{tabular}

Table No.8 represents School climate with respect to management in percent. About $68.66 \%$ of Government and $67.21 \%$ of Aided school teachers reported to have Parents-Teachers Association (PTA) while that of Private is 53.33\%. Out of these who reported to have PTA, $85.86 \%$ of Government, $82.14 \%$ of Private and $47.54 \%$ of Aided school teachers found PTA to be useful for the development of the school. About $62.30 \%$ of Aided, 52.24\% of Government and $44.76 \%$ of Private school teachers reported that local people help for the welfare of the school. It is found that $73.77 \%$ of Aided, $70.95 \%$ of Private and $54.47 \%$ of Government school teachers do not have any kind of outside pressure on them. In terms of Inspection by other organization, $46.88 \%$ of Private, $24.83 \%$ of Government and $21.88 \%$ of Aided school teachers reported that it can be a substitute to the supervisor's inspection.

It can be inferred that Parents-Teachers Association (PTA) are found to be highest in Government schools (67.21\%) and lowest in Private schools(53.33\%). In terms of Local people help, the Aided school teachers $(62.30 \%)$ are more towards the positive side than the other counterparts. It is found that $45.52 \%$ of Government school teachers have pressure from outside 
while that of Aided and Private school teachers is $26.23 \%$ and $29.05 \%$ respectively. This means that teachers are under outside pressure. Inspection by other organization prevails in valley districts of Manipur.

\section{Mode of Teaching With Respect to Management}

Table No.9 : Mode of Teaching (In Percent)

\begin{tabular}{|c|c|c|c|c|c|}
\hline \multirow{2}{*}{$\begin{array}{l}\text { Item } \\
\text { No. }\end{array}$} & \multirow[t]{2}{*}{ Dimensions } & \multirow{2}{*}{$\begin{array}{l}\text { No. of } \\
\text { Respondents }\end{array}$} & \multirow{2}{*}{$\begin{array}{l}\text { Type of } \\
\text { Management }\end{array}$} & \multicolumn{2}{|c|}{ Responses } \\
\hline & & & & Yes & No \\
\hline \multirow[t]{3}{*}{1} & \multirow[t]{3}{*}{ Computer knowledge } & 268 & Government & 26.49 & 73.50 \\
\hline & & 122 & Aided & 27.87 & 72.13 \\
\hline & & 210 & Private & 56.67 & 43.33 \\
\hline \multirow[t]{3}{*}{2} & \multirow[t]{3}{*}{ Use computer in teaching } & 268 & Government & 4.48 & 95.52 \\
\hline & & 122 & Aided & 13.11 & 86.89 \\
\hline & & 210 & Private & 27.14 & 72.86 \\
\hline \multirow[t]{3}{*}{3} & \multirow[t]{3}{*}{ Teach concern subject } & 268 & Government & 64.93 & 35.07 \\
\hline & & 122 & Aided & 65.67 & 34.43 \\
\hline & & 210 & Private & 71.90 & 28.10 \\
\hline \multirow[t]{3}{*}{4} & \multirow[t]{3}{*}{ Use teaching aids } & 268 & Government & 67.54 & 32.46 \\
\hline & & 122 & Aided & 66.39 & 33.60 \\
\hline & & 210 & Private & 60.90 & 38.10 \\
\hline \multirow[t]{3}{*}{5} & \multirow[t]{3}{*}{ Prepare Lesson-plan daily } & 268 & Government & 100 & 0 \\
\hline & & 122 & Aided & 100 & 0 \\
\hline & & 210 & Private & 100 & 0 \\
\hline
\end{tabular}

In terms of Computer knowledge, the Private school teachers are highest $(56.67 \%)$ followed by Aided (27.87\%) and Government $26.47 \%$ ) school teachers subsequently. It is found that $27.14 \%$ of Private, $13.11 \%$ of Aided and $4.48 \%$ of Government school teachers use computer in teaching.

It may be inferred that $73.50 \%$ of Government, $72.89 \%$ of Aided and $43.33 \%$ of Private school teachers do not have computer knowledge. The use of computer is low in all the three types of management with 27.14\%, $13.11 \%$ and $4.48 \%$ of Private, Aided and Government school teachers respectively.

\section{CONCLUSION}

The physical facilities of elementary school teachers for all three types management should be improved. The Private and Aided elementary school teachers should have proper service conditions. The salaries of Private and Unapproved Aided school teachers should commensurate with Government school teachers. Medical benefit must be given to private school teachers also. In-service training should also be expanded to private school teachers. The states of the elementary school teachers must be raised at all possible level.

\section{REFERENCES}

Government of Manipur (1986). Final Report of the Fifth All India Education Survey, Manipur State. Directorate of Education ( S), Imphal, p.10.

Government of India (1966). Education Commission 1964-66. MHRD, New Delhi.

Government of India (1966). Kothari Commission Report. In Sukhla and Rai (1983). Kothari Commission Report, Prakashan Kendra, Lucknow, p.32. 
Government of India (1986). Programme of Action, 1986. MHRD, New Delhi, p.189.

Government of India (1992). The National Policy on Education, 1992. MHRD, New Delhi.

Sharma, R. C. (2002). National Policy on Education and Programme Implimentation. Mangal Deep Publications, Jaipur, p.166.

Government of Manipur (1992). The State Education Commission, Manipur 1992. Report I, Imphal.

Government of Manipur (1992). The State Education Commission, Manipur 1992. Report II, Imphal. 